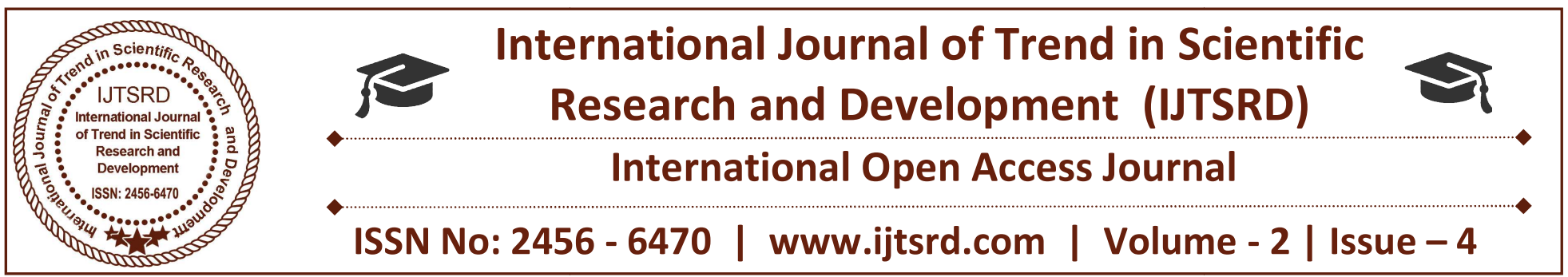

\title{
Biochemical Parameters of Blood Cows at Hight and Low Temperatures
}

\author{
Ward M. Ashraf ${ }^{1}$, Abuargob M. Omry ${ }^{2}$, Hdud M. Ismail ${ }^{3}$, Elgusbi M. Tarek ${ }^{4}$, Ruban Y. Sergey \\ ${ }^{1}$ Department of Preventive Medicine, ${ }^{2}$ Department of Animal Medicine \\ ${ }^{3}$ Department of Pathology and Clinical Pathology, \\ ${ }^{1,2,3}$ Faculty of Veterinary Medicine, University of Tripoli, Tripoli, Libya \\ ${ }^{4}$ Department of Public Health, Faculty of Medical Technology, University of Tripoli, Tripoli, Libya \\ ${ }^{5}$ Institute of Animal breeding and Genetic -NAAS, Kiev-Ukraine
}

\section{ABSTRACT}

Biochemical analysis of blood is a complex laboratory diagnosis conducted to assess the condition of internal organs and systems and to identify the body's need for microelements and the level of its satisfaction. According to the biochemical parameters of the blood composition, primary diagnostics of the functioning of the liver, kidneys, pancreas and other organs is carried out, and data on metabolic processes (lipid, albuminous, carbohydrate metabolisms) are obtained.High and low temperature have a great influence on the physiological processes in the animals, on their thermal state, health, productive qualities, the use of feed, which ultimately determines the efficiency of the work of livestock farms. Season profoundly affected all biochemistry parameters, possibly due to changes in nutrition and disease exposure. Air temperature affects the heat exchange functions of cows. Adverse effects on the body have both a low and high temperature, and especially its sharp fluctuations. Low temperature enhances heat production due to large feed intake by animals, as well as adaptation processes in animals.

Biochemical blood tests are very important for the timely diagnosis of various pathological conditions. Currently, veterinary laboratories in the sample of one animal determine several indicators at once, so the introduction of automatic analyzers is of great importance.

Keywords: Biochemical, blood, Season, temperature, cattle

\section{INTRODUCTION:}

The best adaptive process takes place in cows in the summer period, than winter stables. In the coldest months the adaptation process is decreasing in cows. At the same time, such natural factors as ambient temperature, lack of oxygen in the room, geomagnetic fields, and the duration of daylight time exert their influence on the red blood system and on the biochemical composition of blood in animals.Intensification of dairy cattle breeding and its transfer on an industrial basis raise the raised requirements to a condition of large horned livestock. At present, in the conditions of the Libya and central Russia, the hot and cold method of keeping dairy livestock is widely used, in which livestock is practiced from the first days of life without regulating the microclimate parameters, which contradicts the climatic features of our regions. According to the current requirements for the microclimate of the barns, they must be equipped with ventilation and heating systems to ensure that the rooms have a temperature of $10^{\circ} \mathrm{C}$ and a relative humidity of not more than $75 \%$. These regulatory parameters need to 
be maintained throughout the life of the animals. Those. "Hot, Cold content" acts in violation of these norms. The inconsistency of the microclimate factors in the physiological needs of the organism causes systematic functional disturbances predisposing to the development of such diseases as mastitis, hoof rot, etc. In this connection, it is important to study a loosebox cold method of keeping cows, characterized by the widest spectrum of stress factors.

Phagocytic activity in blood serum in cows in winter was $19.9 \pm 1.4$, in spring $19.0 \pm 2.6$, in summer $17.8 \pm$ 1.9 and in autumn $19.4 \%$. This indicates that there is reason to associate enhanced phagocytosis with adaptive mechanisms that enhance the viability of the organism and its biological stability.

Lysozyme activity in blood serums in winter and autumn in cows was higher than in spring and summer. So, in winter $-26,0 \pm 1,4$, in the autumn $26,4 \pm 1,5 \%$.

Highly productive animals, having an intensive metabolism and energy, are prone to disturbances of homeostasis, the preservation of then tich accompanied by a tension of compensatory mechanisms. The amount of energy spent on adapting to unfavorable conditions, the so-called "price of adaptation," is increasing at the same time. For farm animals, this is expressed in the unproductive consumption of feed and the decrease in productivity. An analysis of the biochemical parameters of the blood allows one to judge the state of carbohydrate, protein, lipid metabolism, to reveal the unproductive energy inputs of the organism $[1,3$, $5,6]$.

The aim of the work is to study the biochemical parameters of cows blood under the influence of negative temperatures of different ranges, in conditions of a cold, hot-free, cold- hot containment method.

\section{Material and methods of investigation:}

The experimental part of the work was performed in the conditions of the dairy farm "Petrovka-1" of the Belgorod region, where 150 cows of red-motley Holstein-Frisian breeds are kept and 50 cow Holstein Frisian at Al-hiera project. The household uses a cold and hot, loose-boxed method of keeping. The study of the peculiarities of adaptation of cows to the effect of low, hight temperatures was carried out in two series of experiments: in the first, the adaptation of cows to the effect of temperature $-5^{\circ} \mathrm{C}$ was studied, in the second: $37^{\circ} \mathrm{C}$, the population of the control group was kept at temperature conditions $+15^{\circ} \mathrm{C}$. Blood sampling was made from the jugular vein at one time under the same external conditions until morning feeding. In the serum, the total protein content was determined; glucose; urea; creatinine; bilirubin, alanine aminotraseferase (ALT) and aspartate aminotransferase (AST) enzymes; cholesterol; thymol test.

All data are expressed as means \pm standard error of mean. Differences in weather data among months were analyzed using one-way analysis of variance (ANOVA). Changes in the growth performance and blood parameters over time were analyzed by repeated-measures ANOVA

\section{Results of own research and discussion:}

Blood indicators are an indicator of the work of the whole organism, they can characterize the level of adaptation of animals to various stressors, including specific conditions of detention [6]. In Table.1 shows the biochemical indicators of blood cows when exposed to a temperature of $-5^{\circ} \mathrm{C}$.

\section{Table 1: Biochemical indicators of blood cows when exposed to a temperature of $-5^{\circ} \mathrm{C}$}

\begin{tabular}{|l|l|l|}
\hline & Groups \\
\hline & Control & An Experience \\
\hline $\begin{array}{l}\text { Glucose, } \\
\mathrm{mmol} / \mathrm{l}\end{array}$ & $3.04 \pm 0.08$ & $2.77 \pm 0.07^{*}$ \\
\hline $\begin{array}{l}\text { Total Protein, } \\
\mathrm{g} / \mathrm{l}\end{array}$ & $80.1 \pm 1.4$ & $80.7 \pm 1.02$ \\
\hline $\begin{array}{l}\text { Urea, } \\
\mathrm{mmol} / \mathrm{g}\end{array}$ & $4.88 \pm 0.09$ & $4.05 \pm 0.34$ \\
\hline $\begin{array}{l}\text { Creatinine, } \\
\mathrm{mmol} / \mathrm{l}\end{array}$ & $71.4 \pm 1.0$ & $62.7 \pm 2.3^{*}$ \\
\hline $\begin{array}{l}\text { Bilirubin, } \\
\mathrm{mmol} / 1\end{array}$ & $8.6 \pm 0.1$ & $18.2 \pm 0.4^{* *}$ \\
\hline $\begin{array}{l}\text { ALT, } \\
\mathrm{mmol}{ }^{*} \mathrm{~h}\end{array}$ & $0.29 \pm 0.01$ & $0.62 \pm 0.01^{* *}$ \\
\hline $\begin{array}{l}\text { AST, } \\
\mathrm{mmol}{ }^{*} \mathrm{~h}\end{array}$ & $0.33 \pm 0.01$ & $0.92 \pm 0.15^{*}$ \\
\hline $\begin{array}{l}\text { Cholesterol, } \\
\mathrm{mmol} / 1\end{array}$ & $5.01 \pm 0.06$ & $3.41 \pm 0.03^{*}$ \\
\hline $\begin{array}{l}\text { Timole Sample, } \\
\text { unit }\end{array}$ & $1.59 \pm 0.07$ & $1.97 \pm 0.13$ \\
\hline
\end{tabular}

Note: significant changes in comparison with the control group (group 1)

$*_{\text {- at }} \mathrm{P}<0,05 ; * *$ - $\mathrm{P}<0.01 ; * * *_{\text {- }} \mathrm{P}<0.001$. 
Under the influence of negative temperature $-5 \mathrm{C}$ the following significant changes in the biochemical parameters of cow's blood were detected: glucose content decreased by $9 \%$, creatinine by $12.2 \%$, cholesterol by $32 \%$, bilirubin content increased by $112 \%$, ALT transamination enzymes by $114 \%$ AST by $179 \%$ compared with the values of the control group.

An analysis of the obtained results of the biochemical composition of the blood in both groups of cows allows us to say that the detected level is within physiological norms. At the same time, fluctuations of individual parameters when comparing control and experimental groups are statistically significant.

In ruminant animals, carbohydrate metabolism plays a significant role in determining the level and intensity of other types of metabolism. The main indicator of the metabolism of carbohydrates is the concentration of sugar in the blood, mainly glucose. Despite the continuous extraction of glucose from the blood, its level in animals remains constant, which is due to absorption from the digestive tract, glycogenolysis, glucogenesis. Maintaining this dynamic balance is possible provided that an increase in tissue requirements in glucose, especially under stress, should be accompanied by an increase in its intake into the blood. Reducing blood sugar is a symptom of a serious violation of carbohydrate metabolism and a lack of glycogen stores in the liver and muscles. Reducing the sugar content in the blood of cows can be seen as the result of a mismatch between the intake of energy and food and its expenditure on metabolic processes and the formation of milk. Those.the revealed differences in the glucose content under the influence of different temperatures can characterize the intensity of the energy component of the adaptation processes [6].

According to a number of authors, the cholesterol content in the blood of healthy cows is in direct correlation with milk productivity. Cholesterol, as an important structural element of the cell membrane, participates in the formation of complexes with proteins of the internal mitochondrial membrane, it can play a definite role in the renewal of membrane lipids of the mammary gland, through its interaction between lipogenesis enzymes and fat precursors. From this it may follow that a lowered level of cholesterol in the blood is associated not only with a decrease in the level of metabolic processes, but also with a decrease in glandular tissue in the udder [5].
In order to assess the health status of cows, under conditions of a cold containment method, aspartate and alanine aminotransferases (AST and ALT) were included in the study system. Significant increases in serum levels of hepatic enzymes ALT and AST can reflect significant organic changes in the functional state of liver cells, the presence of acute and chronic infectious diseases, the probability of occurrence of which increases with the method of treatment [3].

Significant changes in the content of bilirubin and creatinine in the blood serum of experimental cows can determine the intensity of the adaptation mechanisms, namely the degree of decay processes in the body and the decrease in the intensity of protein metabolism.

In Table. 2 shows the biochemical indicators of blood cows when exposed to a temperature of $+37 \mathrm{C}$.

\section{Table 2. Biochemical indicators of blood cows when exposed to a temperature of $+37^{\circ} \mathrm{C}$}

\begin{tabular}{|l|l|l|}
\hline Index & Groups \\
\hline aldournal & Control & An Experience \\
\hline $\begin{array}{l}\text { Glucose, } \\
\text { mmol/1 }\end{array}$ & $3.04 \pm 0.08$ & $4.14 \pm 0.10^{*}$ \\
\hline $\begin{array}{l}\text { Total Protein, } \\
\mathrm{g} / \mathrm{l} \text { dic }\end{array}$ & $80.1 \pm 1.4$ & $69.2 \pm 1.6^{*}$ \\
\hline $\begin{array}{l}\text { Urea, } \\
\text { mmol/g }\end{array}$ & $4.88 \pm 0.09$ & $2.22 \pm 0.18^{*}$ \\
\hline $\begin{array}{l}\text { Creatinine, } \\
\text { mmol/1 }\end{array}$ & $71.4 \pm 1.0$ & $48.6 \pm 0.6^{*}$ \\
\hline $\begin{array}{l}\text { Bilirubin, } \\
\text { mmol/1 }\end{array}$ & $8.6 \pm 0.1$ & $15.2 \pm 0.2^{* *}$ \\
\hline $\begin{array}{l}\text { ALT, } \\
\text { mmol }{ }^{*} h\end{array}$ & $0.29 \pm 0.01$ & $0.52 \pm 0.01^{* *}$ \\
\hline $\begin{array}{l}\text { AST, } \\
\text { mmol } h\end{array}$ & $0.33 \pm 0.01$ & $1.06 \pm 0.25^{*}$ \\
\hline $\begin{array}{l}\text { Cholesterol, } \\
\text { mmol/1 }\end{array}$ & $5.01 \pm 0.06$ & $1.89 \pm 0.13^{*}$ \\
\hline $\begin{array}{l}\text { Timole Sample, } \\
\text { unit }\end{array}$ & $1.59 \pm 0.07$ & $0.71 \pm 0.11^{*}$ \\
\hline
\end{tabular}

Note: significant changes in comparison with the control group (group 1)

* - at $\mathrm{P}<0,05 ; * *$ - $\mathrm{P}<0.01 ; * * *$ - $\mathrm{P}<0.001$.

When exposed to a negative temperature of $+37^{\circ} \mathrm{C}$, significant changes in all the studied biochemical parameters of the blood were noted. In particular, the glucose content increased by $36.2 \%$, bilirubin by $76.7 \%$, ALT enzymes by $79.3 \%$, and AST by $221 \%$, 
respectively, compared with the values of the control group. At the same time, the total protein content decreased by $13.6 \%$, urea by $54.5 \%$, creatinine by $31.9 \%$, cholesterol by $62.3 \%$, timol test significantly decreased by 0.88 units.

The content of total protein in blood serum is an important indicator characterizing the level of metabolism in the animal's body. Proteins are the building material for the cells of body tissues, actively participate in the formation of various types of products. A reliable decrease in the total protein content in the blood of the test group when exposed to a negative temperature of $+37^{\circ} \mathrm{C}$ below the physiological norm $(70-80 \mathrm{~g} / 1)$ can be related to the tension of the adaptation processes, in particular, to a decrease in the level of protein metabolism. The causes of hypoproteinemia may be protein starvation or poor assimilation of proteins from feed due to disorders of the gastrointestinal tract, as well as the mobilization of proteins as sources of energy $[1,2,3]$.

A significant decrease in the urea concentration in the blood serum of the experimental group cows is consistent with the dynamics of the total protein level. Most of the protein in the rumen is hydrolyzed to amino acids, followed by their deamination to ammonia, the excess of which is absorbed into the blood, enters the liver and is converted to urea. Decrease in the level of urea in the serum can indicate the intensity of the synthetic function of the liver or the low degree of disintegration of the protein feed, and accordingly, the violation of protein metabolism [6].

The synthetic function of the liver can be assessed by studying the activity of the transamination enzymes ALT and AST, the main function of which is the synthesis and decomposition of certain amino acids in the body. A significant increase in these indices in the blood of animals of the experimental group is consistent with data on the content of total protein, urea in the serum and indicates a violation of liver function and the intensity of protein metabolism [5].

An increase in the glucose level in the blood serum of cows when exposed to a negative temperature of

$+37^{\circ} \mathrm{C}$ can characterize the presence of stress in animals, in the course of which a release of catecholamines into the blood takes place, which mobilizes the energy reserves of the body (glycogen of the liver and muscles) to overcome the excessive stress effect [5 ].
The decrease in serum cholesterol level detected in our studies can indirectly testify to a decrease in milk production, the level of metabolic processes in the body, and also to occur as a result of the mobilization of lipids as energy sources, compensating for the intensity of other types of metabolism. Switching energy metabolism from carbohydrate type to lipid characterizes the transition to the stage of stress resistance $[4,5]$.

Bilirubin, formed from the hemoglobin of destroyed red blood cells, can characterize the intensity of the stress effect. In our studies, a significant increase in the serum bilirubin content was observed at a temperature effect of $+37^{\circ} \mathrm{C}$, which may indicate the degree of decay processes in the organism under the conditions studied.

Reduction of creatinine in the blood of experimental animals is consistent with data on the content of total protein, urea and determines the tension of protein metabolism, and also indicates insufficient supply of muscle tissue. What can confirm the energy deficiency that develops due to the impossibility of maintaining homeostasis in the conditions under study:

In our studies, there was a significant decrease in the thymol sample, and, accordingly, the content of serum beta and gamma globulins. Timolovaya test - a biochemical test (sediment test), assessing the proteinsynthetic function of the liver. Reduction of this indicator may indicate a decrease in the functional activity of the liver.

\section{CONCLUSIONS:}

When the environmental factors influenced the animals, as well as when changing the habitats of these animals, a quantitative change in the composition and properties of the blood was observed, which is an indicator of the reactivity of the organism and characterizes the natural resistance of cows.

1. When exposed to a temperature of $-5^{\circ} \mathrm{C}$, there are significant differences in the content of glucose, creatinine, bilirubin, ALT and AST enzymes, and cholesterol in the serum of cows.

2. When the temperature $+37^{\circ} \mathrm{C}$ was influenced, significant changes were observed in all the studied biochemical indices of the blood of cows: glucose, 
total protein, urea, creatinine, bilirubin, ALT, AST, cholesterol, thymol assay.

3. The content of the total protein, enzymes ALT, AST at a temperature effect of $+37^{\circ} \mathrm{C}$ goes beyond the limits of the physiological norm, which confirms the violation of homeostasis when adapting to the conditions under study.

\section{REFERENCES:}

1) Yudin MF The physiological state of the organism of cows in different seasons of the year. // Veterinary Medicine-2001.-№2-p.38-41.

2) Safonov VA, Nezhdanov AG, Retsky MI, Shushlebin V.I. Changes in biochemical parameters of blood in highly productive cows in the second half of pregnancy and in the postpartum period. // Bulletin of the Russian Academy of Agricultural Sciences.-2008.-№3.p.74-76.

3) Retskiy M.I. System of antioxidant protection in animals under stress and its pharmacological regulation: the Author's abstract of the thesis of the Doctor of Biological Sciences.-Voronezh, 1997.
4) Kolosov AA, DudkinAL Epizootological monitoring of classical and factor diseases of farm animals. // Modern problems of epizootology. Materials of the International Scientific Conference (Krasnoobsk, June 30, 2004). Novosibirsk., 2004.-p.119-126.

5) Kondrakhin IP, Kurilov NV, MalakhovAG Clinical laboratory diagnostics in veterinary medicine. - M: Agropromizdat.-1985.-p.287.

6) Usovich A.T., Lebedev P.T. Application of mathematical statistics in the processing of experimental data in veterinary medicine. SibNIIV. - Omsk .- 1970.-p.43.

7) 8.Chen X., Jiang R., \&Geng Z. 2012. Cold stress in broiler: Global gene expression analyses suggest a major role of $\mathrm{CYP}$ genes in cold responses. MolBiol Rep. 39:425-429.

8) 9.Ghazavi A., Mosayebi G., Solhi H., Rafiei M., \&Moazzeni SM. 2013. Serum markers of inflammation and oxidative stress in chronic opium (Taryak) smokers. Immunol Let. 153:2226. 